\title{
Pemodelan PDRB di Indonesia Menggunakan Pendekatan Regresi Nonparametrik Spline
}

\author{
Puspita Khanela, Madu Ratna, dan I Nyoman Budiantara \\ Departemen Statistika, Fakultas MIPA, Institut Teknologi Sepuluh Nopember (ITS) \\ e-mail: i_nyoman_b@statistika.its.ac.id
}

\begin{abstract}
Abstrak-Pertumbuhan ekonomi pada tahun 2015 mengalami perlambatan dibandingkan dengan tahun sebelumnya, penyebab perlambatan ekonomi terlihat dari berbagai sisi yaitu sisi pengeluaran pada konsumsi rumah tangga dan konsumsi pemerintah. Pertumbuhan ekonomi adalah suatu kondisi dimana terjadi peningkatan suatu produk domestik bruto, pertumbuhan ekonomi suatu daerah dikatakan meningkat apabila terjadi kenaikan Produk Domestik Regional Bruto. Faktor yang diduga mempengaruhi PDRB sebagai indikator laju pertumbuhan ekonomi yaitu TPAK, Penanaman Modal Asing, Realisasi Belanja Modal dan Realisasi Belanja Pegawai. Faktor yang berpengaruh terhadap pertumbuhan ekonomi di Indonesia diindikasikan tidak adanya jaminan yang menunjukan adanya pengaruh salah satu faktor dapat meningkatkan pertumbuhan ekonomi ataupun sebaliknya sehingga penelitian ini dapat dilakukan menggunakan analisis pendekatan Regresi Nonparametrik Spline. Setelah dilakukan analisis didapatkan bahwa model terbaik menggunakan kombinasi knot 2-3-2-3 memenuhi asumsi IIDN dan diapatkan $R^{2}$ sebesar $99,207 \%$.
\end{abstract}

Kata Kunci-Produk Domestik Regional Bruto, Indonesia, Regresi Nonparametrik Spline.

\section{PENDAHULUAN}

$\mathrm{P}$ ERTUMBUHAN ekonomi di Indonesia sering mengalami fluktuasi hal tersebut disebabkan adanya perubahan pada

kondisi internal maupun eksternal. Pada tahun 2015 pertumbuhan ekonomi mengalami perlambatan dari tahun sebelumnya. Penyebab dari melambatnya perekonomian di tahun 2015 terlihat dari sisi pengeluaran yaitu konsumsi rumah tangga dan konsumsi pemerintah yang melambat [1]. Pertumbuhan ekonomi merupakan suatu proses berkembangnya kondisi ekonomi di suatu wilayah dari waktu ke waktu [2]. Dinamika pertumbuhan ekonomi dapat terlihat dari perubahan nilai PDRB di masing-masing daerah, apabila semakin meningkat nilai PDRB maka pertumbuhan ekonomi juga semakin meningkat. Nilai PDRB sebagai indikator untuk mengetahui kondisi ekonomi yang terbagi menjadi dua yaitu atas dasar harga berlaku dan atas dasar harga konstan. PDRB atas dasar harga berlaku menggambarkan nilai barang dan jasa yang dihitung menggunakan harga pada tahun berjalan, sedangkan PDRB atas dasar harga konstan menggambarkan nilai tambah barang dan jasa yang dihitung menggunakan harga berlaku pada satu tahun tertentu sebagai tahun dasar [3]. PDRB atas dasar harga konstan digunakan untuk mengetahui pertumbuhan ekonomi secara riil dari tahun ke tahun dengan menggunakan tahun dasar 2010.

Secara nasional, perekonomian Indonesia mengalami perlambatan dan hanya mampu tumbuh $4,79 \%$ lebih rendah dibandingkan tahun 2014 yaitu sebesar 5,02\% [2]. Struktur ekonomi di Indonesia didominasi oleh Pulau Jawa dan Sumatera yang mampu memberikan kontribusi terbesar terhadap PDRB. Perekonomian global diwarnai penurunan harga komoditas, terutama harga minyak menjadi faktor eksternal yang memberikan pengaruh melambatnya perekonomian global [4]. Sementara itu, dari faktor internal perlambatan ekonomi di dalam negeri disebabkan rendahnya eksekusi belanja infrastuktur pemerintah yaitu di bidang infrastruktur yang belum banyak terealisasi [2]. Permasalahan ekonomi yang terjadi pada tahun 2015 akan diakukan penelitian yang fokus pada pemodelan PDRB di Indonesia.

Faktor yang membentuk PDRB diantaranya TPAK, Penanaman Modal Asing, Realisasi belanja modal dan realisasi belanja pegawai. Berdasarkan faktor-faktor tersebut diindikasikan tidak adanya jaminan yang menunjukkan pengaruh dari salah satu faktor mampu meningkatkan pertumbuhan ekonomi atau sebaliknya. Hal ini mendukung tujuan untuk memodelkan PDRB menggunakan metode pendekatan Regresi Nonparametrik Spline karena berdasarkan rujukan sebelumnya memiliki plot data yang tidak membentuk suatu pola. Model terbaik yang dihasilkan akan dilakukan prediksi terhadap PDRB selanjutnya yang terbia menjadi tiga yaitu skenario prediksi model optimis, middle, dan pesimis dengan syarat variabel prediktor memenuhi syarat. Pendekatan Regresi Nonparametrik Spline digunakan untuk mengetahui hubungan antara variabel respon dan variabel prediktor yang fungsinya belum diketahui atau kurva regresi tidak membentuk suatu pola. Setelah didapatkan model terbaik selanjutnya dilakukan pengujian IIDN dengan tujuan untuk mengetahui apakah residual yang dihasilkan memenuhi asumsi atau tidak.

Penelitian mengenai pertumbuhan ekonomi telah dilakukan beberapa peneliti sebelumnya. Variabel investasi, tenaga kerja, tingkat pendidikan menggunakan metode regresi data panel oleh Fauzan [5]. Litawati [6] dan [7] melakukan penelitian dengan menggunakan pendekatan Regresi Nonparametrik Spline dengan menggunakan variabel TPAK, Jumlah industri besar dan sedang, DAU dan APBD.

\section{TINJAUAN PUSTAKA}

\section{A. Statistika Deskriptif}

Diagram batang yang digambarkan secara tegak disebut diagram batang tegak dan yang digambarkan secara mendatar disebut diagram batang mendatar [8].

\section{B. Regresi Nonparametrik Spline}

Metode statistika yang digunakan untuk mengetahui hubungan antar variabel respon dengan variabel prediktor 
yaitu Regresi Nonparametrik Spline dimana kurva regresi tidak membentuk suatu pola tertentu. Regresi Nonparametrik Spline memiliki tingkat fleksibilitas yang tinggi [9].

Model regresi nonparametrik secara umum adalah sebagai berikut.

$$
y_{i}=f\left(x_{i}\right)+\varepsilon_{i} \quad i=1,2,3, \ldots . n
$$

dimana $y_{i}$ merupakan variabel respon, $x_{i}$ adalah variabel prediktor dan $f\left(x_{i}\right)$ merupakan fungsi regresi yang tidak membentuk suatu pola dan $\varepsilon_{i}$ merupakan error yang identik, independen dan berdistribusi normal $\left(\mathrm{N} \sim\left(0, \sigma^{2}\right)\right)$. Spline merupakan potongan polinomial yang memiliki sifat tersegmen yang dapat memberikan fleksibilitas lebih baik dari polinomial biasa sehingga dapat menyesuaikan diri lebih efektif adanya karakteristik dari suatu fungsi atau data. Misalkan terdapat data berpasangan sebagai berikut.

$$
\left(x_{1 i}, x_{2 i}, \ldots x_{k i}, y_{i}\right)
$$

Hubungan antara kedua data tersebut mengikuti model regresi nonparametrik sehingga menjadi persamaan berikut.

$$
y_{i}=f\left(x_{1 i}, x_{2 i}, \ldots x_{k i}\right)+\varepsilon_{i} \quad i=1,2,3, \ldots . n
$$

(2)

dengan $y_{i}$ merupakan variabel respon dan $f$ merupakan kurva regresi yang tidak membentuk pola tertentu. Apabila kurva regresi $f$ merupakan model aditif dan dihampiri dengan fungsi spline maka model regresi dapat diperoleh sebagai berikut.

$$
\begin{aligned}
y_{i} & =\sum_{j=1}^{p} f\left(x_{j i}\right)+\varepsilon_{i} \quad ; i=1,2,3, \ldots . n \\
& =f\left(x_{1 i}\right)+f\left(x_{2 i}\right)+\ldots .+f\left(x_{p i}\right)+\varepsilon_{i}
\end{aligned}
$$

dimana

$$
f\left(x_{j i}\right)=\sum_{h=0}^{q} \beta_{h j} x_{j i}^{h}+\sum_{l=1}^{m} \beta_{(q+1) j}\left(x_{j i}-K_{l j}\right)_{+}^{q}
$$

dan

$$
\left(x_{j i}-K_{l j}\right)_{+}^{q}=\left\{\begin{array}{cl}
\left(x_{j i}-K_{l j}\right)^{q} & , x_{j i} \geq K_{l j} \\
0 & , x_{j i}<K_{l j}
\end{array}\right.
$$

Nilai-nilai $K_{l j}, K_{2 j}, \ldots, K_{m j}$ merupakan titik knot yang memperlihatkan pola perubahan dari fungsi pada sub interval yang berbeda. Nilai $q$ pada persamaan (4) merupakan derajat polinomial. Kurva polinomial dalam penelitian ini yaitu derajat satu atau disebut dengan kurva liniear. Persamaan 3 dapat diuraikan menjadi persamaan (5) sebagai berikut.

$$
\begin{aligned}
y_{i}= & \beta_{00}+\beta_{l 1} x_{l i}+\ldots+\beta_{q 1} x_{l i}^{q}+\beta_{l 1}\left(x_{l i}-K_{l 1}\right)_{+}^{q}+\ldots+\beta_{m 1}\left(x_{l i}-K_{m 1}\right)_{+}^{q}+ \\
& \beta_{l 2} x_{2 i}+\ldots+\beta_{q 2} x_{2 i}^{q}+\beta_{l 2}\left(x_{2 i}-K_{l 2}\right)_{+}^{q}+\ldots+\beta_{m 2}\left(x_{2 i}-K_{m 2}\right)_{+}^{q}+ \\
& \beta_{l p} x_{p i}+\ldots+\beta_{q p} x_{p i}^{q}+\beta_{l p}\left(x_{p i}-K_{l p}\right)_{+}^{q}+\ldots+\beta_{m p}\left(x_{p i}-K_{p 1}\right)_{+}^{q}+\varepsilon_{i}
\end{aligned}
$$

Estimasi untuk $\beta$ dapat dilihat pada persamaan (6) sebagai berikut.

$$
\mathcal{\beta}=\left(X^{T} X\right)^{-1} X^{T} y
$$

\section{Pemilihan Titik Knot Optimal}

Metode yang digunakan untuk pemilihan titik knot optimal adalah Generalized Cross Validation (GCV) dengan nilai paling minimum. Fungsi GCV diberikan sebagai berikut [9].

$$
G C V\left(k_{1}, k_{2}, \ldots, k_{J}\right)=\frac{\operatorname{MSE}\left(k_{1}, k_{2}, \ldots, k_{J}\right)}{\left(n^{-1} \operatorname{Tr}\left[I-A\left(k_{1}, k_{2}, \ldots, k_{J}\right)\right]\right)^{2}}
$$

dengan

$$
\begin{aligned}
& y=A\left(k_{1}, k_{2}, \ldots, k_{J}\right) \mathrm{y} \\
& A\left(k_{1}, k_{2}, \ldots, k_{J}\right)=X\left(X^{T} X\right)^{-1} X^{T}
\end{aligned}
$$

$\operatorname{MSE}\left(k_{1}, k_{2}, \ldots, k_{J}\right)=n^{-1} \sum_{i=1}^{n}\left(y_{i}-y_{i}\right)^{2}$

\section{Koefisien Determinasi}

Koefisien determinasi merupakan kuantitas yang dapat menjelaskan sumbangan variabel prediktor dan menjelaskan variabilitas terhadap variabel respon [10]. Berikut adalah rumus untuk menghitung Koefisien determinasi $\left(R^{2}\right)$.

$$
R^{2}=\frac{S S_{\text {Re gresi }}}{S S_{\text {total }}}=\frac{\sum_{i=1}^{n}\left(y_{i}-\bar{y}\right)^{2}}{\sum_{i=1}^{n}\left(y_{i}-\bar{y}\right)^{2}}
$$

Keterangan :

$S S_{\text {regresi }}$ : Jumlah Kuadrat Regresi

SStotal : Jumlah Kuadrat Total

\section{E. Pengujian Parameter Model}

Pengujian parameter dilakukan untuk mengetahui suatu variabel terdapat pengaruh yang signifikan terhadap model atau tidak secara serentak dan parsial. Diberikan model Regresi Nonparametrik Spline seperti pada persamaan (9) sebagai berikut.

$$
y_{i}=\sum_{j=0}^{m} \beta_{j} x_{i}^{j}+\sum_{k=1}^{r} \beta_{m+k}\left(x_{i}-K_{k}\right)_{+}^{m}+\varepsilon_{i}
$$

Berdasarkan pada persamaan diatas maka pengujian secara serentak dan parsial sebagai berikut [10].

1. Pengujian parameter model secara serentak

Pengujian parameter secara serentak yaitu pengujian yang dilakukan secara bersama-sama dengan hipotesis sebagai berikut.

$\mathrm{H}_{0}: \beta_{1}=\beta_{2}=\beta_{3}=\ldots=\beta_{m+r}=0$

$\mathrm{H}_{1}$ : minimal ada satu $\beta_{\mathrm{j}} \neq 0 ; \mathrm{j}=1,2, \ldots \mathrm{m}+\mathrm{r}$

Statistik uji :

$$
F_{\text {hitung }}: \frac{M S_{\text {regresi }}}{M S_{\text {eror }}}
$$

Daerah penolakan dala pengujian ini yaitu menolak $\mathrm{H}_{0}$ apabila $\mathrm{F}_{\text {hitung }}>\left(\mathrm{F}_{\alpha ;(\mathrm{m}+\mathrm{r}, \mathrm{n}-(\mathrm{m}+\mathrm{r})-1)}\right)$.

2. Pengujian parameter model secara parsial

Pengujian parameter model secara parsial dilakukan secara individu. Statistik uji dalam pengujian ini dapat dijelaskan dalam persamaan (11).

$\mathrm{H}_{0}: \beta_{j}=0$

$\mathrm{H}_{1}$ : Minimal ada satu $\beta_{j} \neq 0, j=1,2, \ldots ., m+r$

Daerah Penolakan : Menolak $\mathrm{H}_{0}$ apabila nilai dari $\left|\mathrm{t}_{\text {hitung }}\right|>\mathrm{t}_{\alpha / 2}$, $\mathrm{n}-(\mathrm{m}+\mathrm{r})-1$. Statistik uji yang digunakan pada pengujian parameter model secara parsial adalah

$$
t_{\text {hitung }}=\frac{\hat{\beta}_{j}}{\operatorname{SE}\left(\hat{\beta}_{j}\right)}
$$

\section{F. Pengujian Asumsi Residual}

Pengujian asumsi residual dilakukan untuk mengetahui apakah residual data memenuhi asumsi identik, independen dan berdistribusi normal atau tidak. Pengujian terhadap asumsi identik dilakukan dengan menggunakan uji Glejser. Pengujian residual identik dilakukan untuk melihat apakah residual memenuhi asumsi identik atau tidak. Residual dikatakan identik apabila plot residualnya menyebar secara acak dan 
tidak membentuk suatu pola [11] kemudian untuk mengetahui apakah residual data memenuhi asumsi independen yaitu dengan mendeteksi adanya kasus autokorelasi salah satunya yaitu memeriksa plot antara $y$ taksiran dengan orde. Apabila plot menyebar secara acak maka asumsi independen telah terpenuhi [11]. Pengujian asumsi residual berdistribusi normal mempunyai tujuan untuk mengetahui apakah residual telah mengikuti distribusi normal atau tidak menggunakan uji Kolmogorov [12].

\section{G. Pertumbuhan Ekonomi}

Pertumbuhan ekonomi adalah kondisi dimana terjadi peningkatan produk domestik bruto dari suatu negara atau daerah tanpa memandang kenaikan tersebut lebih besar atau lebih kecil dari tingkat pertumbuhan penduduk [13]

\section{H. Produk Domestik Regional Bruto (PDRB)}

PDRB merupakan salah satu indikator penting untuk mengetahui kondisi ekonomi di suatu daerah dalam suatu periode tertentu, baik atas dasar berlaku maupun atas dasar harga konstan. PDRB konstan digunakan untuk mengetahui pertumbuhan ekonomi secara riil dari tahun ke tahun atau pertumbuhan ekonomi yang tidak dipengaruhi oleh faktor harga [3].

\section{METODOLOGI PENELITIAN}

\section{A. Sumber Data}

Data yang digunakan dalam penelitian ini merupakan data sekunder yang didapatkan dari BPS (Badan Pusat Statistik) Nasional yang terdiri dari Publikasi Statistik Indonesia 2016 dan Statistik Keuangan 2012-2015. Objek penelitian ini terdiri dari 34 Provinsi di Indonesia.

\section{B. Variabel Penelitian}

Variabel yang digunakan pada penelitian ini dideskripsikan pada Tabel 1 .

Tabel 1.

Variabel Penelitian

\begin{tabular}{cccc}
\hline \hline Variabel & Jenis Variabel & Notasi & satuan \\
\hline Produk Domestik & Variabel Respon & $\mathrm{Y}$ & Trilliun \\
Regional Bruto & & & \\
Tingkat Partisipasi & Variabel Prediktor & $\mathrm{X}_{1}$ & Persentase \\
Angkatan Kerja & & & Miliar US\$ \\
Investasi Penanaman & Variabel Prediktor & $\mathrm{X}_{2}$ & Trilliun \\
Modal Asing & Variabel Prediktor & $\mathrm{X}_{3}$ & Trilliun \\
$\begin{array}{c}\text { Realisasi Belanja Modal } \\
\text { Realisasi Belanja } \\
\text { Pegawai }\end{array}$ & Variabel Prediktor & $\mathrm{X}_{4}$ & \\
\hline \hline
\end{tabular}

\section{Langkah Analisis}

Langkah analisis dalam melakukan penelitian ini adalah sebagai berikut.

1. Melakukan eksplorasi terhadap data nilai PDRB sebagai indikator laju pertumbuhan ekonomi di Indonesia.

2. Memodelkan PDRB sebagai indikator laju pertumbuhan ekonomi di Indonesia menggunakan analisis Regresi Nonparametrik Spline dengan langkahlangkah sebagai berikut.

a. Membuat Scatterplot antara variabel respon dan variabel prediktor untuk mengetahui pola data b. Memodelkan variabel respon menggunakan Regresi Nonparametrik Spline dengan satu, dua, tiga dan kombinasi knot.

c. Menentukan titik-titik knot optimal menggunakan GCV minimum

d. Menetapkan model Regresi Nonparametrik Spline terbaik

e. Menguji signifikansi parameter secara serentak dan individu

f. Melakukan uji IIDN pada residual

g. Menginterpretasi model, dan membuat suatu kebijakan untuk PDRB pesimis, rata-rata dan optimis bagi pemerintah setempat.

3. Menarik Kesimpulan

\section{ANALISIS DAN PEMBAHASAN}

\section{A. Karakteristik PDRB di Indonesia Tahun 2015}

Karakteristik PDRB di Indonesia pada tahun 2015 diperoleh nilai terendah sebesar 20,4 Trilliun di Provinsi Maluku Utara sedangkan nilai tertinggi sebesar sebesar 1454,3 Trilliun di provinsi DKI Jakarta. Rata-rata PDRB mencapai 265,7 dan nilai standar deviasi mencapai 376,2 yang menunjukkan keragaman data PDRB atas dasar harga konstan yang cukup besar. Pada variabel TPAK nilai maksimum sebesar 79,569 pada provinsi Papua dan nilai terendah sebesar 60,340 pada provinsi Jawa Barat kemudian paada variabel PMA nilai maksimum sebesar 5,739 pada provinsi Jawa barat dan nilai minimum sebesar 0,002 pada provinsi Sulawesi Barat. Pada variabel relialisasi belanja modal nilai minimum sebesar 0,311 pada provinsi Kepulauan Bangka Belitung dan nilai maksimum sebesar 22,278 pada provinsi Aceh dan variabel relialisasi belanja pegawai nilai minimum sebesar 0,241 pada provinsi Sulawesi Barat dan nilai maksimum sebesar 21,097 pada provinsi DKI Jakarta.

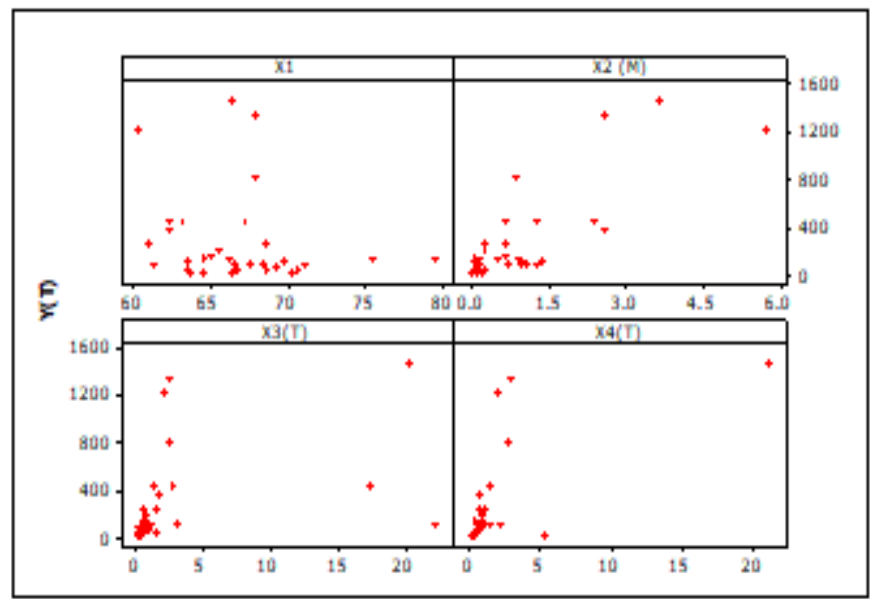

Gambar 1. Plot Data Antara Variabel Respon Dengan Variabel Prediktor.

Pola hubungan antara variabel respon yaitu PDRB dengan variabel prediktor meliputi TPAK, PMA, Realisasi belanja modal dan Realisasi belanja pegawai yang ditunjukan Gambar 1 menunjukkan bahwa pola yang terbentuk dari grafik tersebut tidak membentuk suatu pola sehingga termasuk komponen dari nonparametrik. 


\section{B. Pemilihan Model Optimum}

Hasil pemodelan regresi nonparametrik spline keseluruhan iterasi knot yaitu satu, dua, tiga dan kombinasi knot selanjutnya dilakukan pemilihan titik knot yang paling optimum dengan rincian sebagai berikut.

Tabel 2.

Pemilihan Titik Knot Optimum

\begin{tabular}{cc}
\hline \hline Model Regresi Spline Linear & Nilai GCV \\
\hline 1 knot & 28694,9 \\
2 knot & 14963,7 \\
3 knot & 3485,19 \\
kombinasi knot & 3150,55 \\
\hline
\end{tabular}

Tabel 2 didapatkan nilai GCV paling minimum adalah sebesar 3150,55 dengan kombinasi knot 2-3-2-3 dari masingmasing prediktor sebagai berikut.

$$
\begin{aligned}
& X_{1}=64,65638 ; 76,42933 \\
& X_{2}=1,289856 ; 1,375232 ; 4,802109 \\
& X_{3}=5,242154 ; 18,6919 \\
& X_{4}=4,923344 ; 7,051515 ; 17,69237
\end{aligned}
$$

Sehingga model regresi nonparametriknya adalah sebagai berikut.

$$
\begin{aligned}
\hat{y}= & -576,916+7,506 x_{1}-15,783\left(x_{1}-64,656\right)_{+}^{1}-61,509\left(x_{1}-76,429\right)_{+}^{1}+13,617 x_{2}- \\
& 7867,562\left(x_{2}-1,290\right)_{+}^{1}+14945,791\left(x_{2}-1,875\right)_{+}^{1}-23655,847\left(x_{2}-4,802\right)_{+}^{1}+64,546 x_{3}+ \\
& 3,396\left(x_{3}-5,242\right)_{+}^{1}-462,376\left(x_{3}-18,692\right)_{+}^{1}+263,511 x_{4}-3013,684\left(x_{4}-4,923\right)_{+}^{1}+ \\
& 2447,259\left(x_{4}-7,502\right)_{+}^{1}+593,274\left(x_{4}-17,692\right)_{+}^{1}
\end{aligned}
$$

Berdasarkan model kombinasi knot diatas menghasilkan nilai $\mathrm{R}^{2}$ sebesar $99.207 \%$

\section{Pengujian Parameter Model Regresi Nonparametrik Spline}

Pengujian parameter model Regresi Nonparametrik Spline dilakukan secara serentak dan individu dengan tujuan untuk mengetahui apakah variabel-variabel prediktor memberikan pengaruh secara signifikan dalam model.

\section{Pengujian Parameter Serentak}

Pengujian parameter secara serentak menggunakan uji $F$ dengan hipotesis yang digunakan sebagai berikut.

$\mathrm{H}_{0}: \beta_{1}=\beta_{2}=\beta_{3}=\mathrm{K}=\beta_{15}=0$

$\mathrm{H}_{1}$ : minimal ada satu $\beta_{j} \neq 0 ; j=1,2 . ., 15$

Tabel ANOVA dari model Regresi Nonparametrik Spline disajikan pada Tabel 3

Tabel 3. ANOVA Model Regresi Nonparametrik Spline

\begin{tabular}{ccrrcc}
\hline \hline Sumber & df & \multicolumn{1}{c}{ SS } & \multicolumn{1}{c}{ MS } & Fhitung & P-value \\
\hline Regresi & 14 & 4635148 & 331082 & 169,7155 & $6,752408 \mathrm{e}^{-17}$ \\
Error & 19 & 37065,31 & 1950,806 & & \\
Total & 33 & 4672213 & & & \\
\hline \hline
\end{tabular}

Tabel 3. diperoleh keputusan $\mathrm{H}_{0}$ ditolak karena $\mathrm{F}_{\text {hitung }}$ sebesar 169,7155 lebih dari $\mathrm{F}_{(14,19 ; 0,05)}$ sebesar 2,255 sehingga minimal ada satu parameter yang signifikan terhadap model.

2. Pengujian Parameter Parsial
Setelah dilakukan pengujian secara serentak kemudian dilakukan pengujian parameter secara individu menggunakan uji

\begin{tabular}{|c|c|c|c|c|}
\hline Variabel & parameter & Estimator & $P$-value & keterangan \\
\hline constant & $\beta_{0}$ & $-576,915841$ & 0,371045 & $\begin{array}{c}\text { Tidak } \\
\text { Signifikan }\end{array}$ \\
\hline \multirow[t]{3}{*}{$\mathrm{X}_{1}$} & $\beta_{1}$ & 7,506658 & 0,4562304 & $\begin{array}{c}\text { Tidak } \\
\text { Signifikan }\end{array}$ \\
\hline & $\beta_{2}$ & $-15,783499$ & 0,2141977 & $\begin{array}{c}\text { Tidak } \\
\text { Signifikan }\end{array}$ \\
\hline & $\beta_{3}$ & $-61,509380$ & 0,0188333 & Signifikan \\
\hline \multirow[t]{4}{*}{$\mathrm{X}_{2}$} & $\beta_{4}$ & 13,617175 & 0,5922094 & $\begin{array}{c}\text { Tidak } \\
\text { Signifikan }\end{array}$ \\
\hline & $\beta_{5}$ & $-7867,561668$ & $5,594559 \mathrm{e}-08$ & Signifikan \\
\hline & $\beta_{6}$ & 14945,790913 & $2,933017 \mathrm{e}-08$ & Signifikan \\
\hline & $\beta_{7}$ & $-23655,847245$ & $2,107567 \mathrm{e}-08$ & Signifikan \\
\hline \multirow[t]{3}{*}{$\mathrm{X}_{3}$} & $\beta_{8}$ & 64,546253 & 0,00151494 & Signifikan \\
\hline & $\beta_{9}$ & 3,395937 & 0,9057855 & $\begin{array}{c}\text { Tidak } \\
\text { Signifikan }\end{array}$ \\
\hline & $\beta_{10}$ & $-462,376406$ & $3,124122 \mathrm{e}-07$ & Signifikan \\
\hline \multirow[t]{4}{*}{$\mathrm{X}_{4}$} & $\beta_{11}$ & 263,510641 & $1,698394 \mathrm{e}-11$ & Signifikan \\
\hline & $\beta_{12}$ & $-3013,684079$ & $1,649021 \mathrm{e}-10$ & Signifikan \\
\hline & $\beta_{13}$ & 2447,259169 & $6,010361 \mathrm{e}-09$ & Signifikan \\
\hline & $\beta_{14}$ & 593,274167 & $6,010361 \mathrm{e}-09$ & Signifikan \\
\hline
\end{tabular}
$t$ dengan hipotesis sebagai berikut.

$\mathrm{H}_{0}: \beta_{j}=0$

$\mathrm{H}_{1}$ : minimal ada satu $\beta_{j} \neq 0$

Hasil estimator dari masing-masing parameter dapat ditunjukkan pada Tabel 4. sebagai berikut.

Tabel 4.

Pengujian Parameter Secara Individu

Tabel 4 diperoleh hasil yang menyatakan bahwa seluruh variabel yaitu TPAK $\left(\mathrm{X}_{1}\right)$, Penanaman Modal Asing $\left(\mathrm{X}_{2}\right)$, Realisasi belanja modal $\left(\mathrm{X}_{3}\right)$ dan Realisasi belanja pegawai $\left(\mathrm{X}_{4}\right)$ signifikan.

\section{Pengujian Asumsi Residual}

Pengujian asumsi residual dilakukan untuk mengetahui apakah residual memenuhi asumsi yaitu identik, independen dan berdistribusi normal. Setelah dilakukan analisis pada residual data menghasilkan bahwa residual data memenuhi asumsi identik, independen dan berdistribusi normal.

\section{E. Interpretasi Model Optimis, Middle dan Pesimis}

Prediksi model optimis, middle dan pesimis didapatkan dari model terbaik yang memiliki GCV terkecil. Prediksi model optimis merupakan prediksi pada wilayah yang berada diatas rata-rata kemudian untuk prediksi middle merupakan prediksi pada wilayah yang berada di rata-rata sedangkan prediksi model pesimis merupakan prediksi wilayah yang berada di bawah rata-rata. Berdasarkan analisis dan pembahasan yang telah dilakukan sebelumnya, apabila mengharapkan PDRB yang telah ditetapkan maka sebaiknya pemerintah mampu mengendalikan beberapa variabel prediktor sehingga prediksi 
nilai PDRB akan dapat terpenuhi. Hasil prediksi model ditunjukkan pada Tabel 5.

Tabel 5.

Prediksi model optimum, middle dan pesimis

\begin{tabular}{ccccccc}
\hline \hline Wilayah & TPAK & PMA & $\begin{array}{c}\text { Realisasi } \\
\text { Belanja } \\
\text { Modal }\end{array}$ & $\begin{array}{c}\text { Realisasi } \\
\text { Belanja } \\
\text { Pegawai }\end{array}$ & $\begin{array}{c}\text { Prediksi } \\
\text { Nilai } \\
\text { PDRB }\end{array}$ & $\begin{array}{c}\text { Skenario } \\
\text { Model }\end{array}$ \\
\hline $\begin{array}{c}\text { DKI } \\
\text { Jakarta }\end{array}$ & 79,58 & 3,9 & 22,69 & 22,15 & 1462,57 & \\
$\begin{array}{c}\text { Jawa Timur } \\
\text { Jawa }\end{array}$ & 77,50 & 2,6 & 2,7 & 3,3 & 1344,66 & Optimis \\
Barat & 76,55 & 2,58 & 2,43 & 3,12 & 1211,70 & \\
\hline Bali & 76,33 & 0,69 & 0,68 & 1,01 & 131,20 & \\
Jambi & 73,44 & 0,57 & 0,64 & 0,93 & 129,82 & Middle \\
Kalimantan & 72,79 & 0,49 & 0,61 & 0,88 & 119,00 & \\
Barat & & & & \\
\hline Maluku & 69,55 & 0,1 & 0,51 & 0,47 & 26,01 & \\
Gorontalo & 67,50 & 0,09 & 0,46 & 0,41 & 23,81 & Pesimis \\
Maluku & 66,55 & 0,08 & 0,42 & 0,385 & 22,36 & \\
\hline Utara & 66,55 & & & & &
\end{tabular}

Berdasarkan hasil prediksi yang ditunjukkan Tabel 5 diperoleh 3 wilayah tertinggi yang masuk dalam prediksi model optimis PDRB yaitu DKI Jakarta, Jawa Timur dan Jawa Barat berdasarkan syarat variabel prediktor telah memenuhi. Pada wilayah DKI Jakarta prediksi niai PDRB sebesar 1462,57 Triliun dengan variabel prediktor TPAK sebesar 79,58, PMA 3,9, Realisasi belanja modal sebesar 22,69 dan realisasi belanja pegawai sebesar 22,15 . Selanjutnya wilayah kedua yaitu Jawa Timur dengan prediksi nilai PDRB sebesar 1344,66 dengan variabel TPAK sebesar 77,50, Variabel PMA sebesar 3,9, Variabel Realisasi belanja modal sebesar 2,7 dan variabel realisasi belanja pegawai sebesar 3,3 kemudian untuk Wilayah Jawa Barat prediksi nilai PDRB sebesar 1211,70 dengan variabel TPAK sebesar 76,50, Variabel PMA sebesar 2,58, Variabel Realisasi belanja modal sebesar 2,43 dan variabel realisasi belanja pegawai sebesar 3,12.

Model prediksi middle berdasarkan 3 wilayah yang berada di rata-rata yaitu Bali, Jambi dan Kalimantan Barat. Pada wilayah Bali prediksi nilai PDRB 131,20 dengan variabel TPAK sebesar 76,33, Variabel PMA sebesar 0,69, Variabel Realisasi belanja modal sebesar 0,68 dan variabel realisasi belanja pegawai sebesar 1,01. Selanjutnya pada wilayah Jambi dengan prediksi nilai PDRB sebesar 129,82 dengan variabel TPAK sebesar 73,44, Variabel PMA sebesar 0,57, Variabel Realisasi belanja modal sebesar 0,64 dan variabel realisasi belanja pegawai sebesar 0,93 kemudian pada wilayah Kalimantan barat dengan prediksi nilai PDRB sebesar 119 dengan variabel TPAK sebesar 72,79, Variabel PMA sebesar 0,49 , Variabel Realisasi belanja modal sebesar 0,61 dan variabel realisasi belanja pegawai sebesar 0,88 .

Pada model prediksi pesimis dengan 3 wilayah terendah yaitu pada wilayah Maluku, Gorontalo dan Maluku Utara. Pada wilayah Maluku nilai prediksi PDRB adalah sebesar 26,01 dengan variabel TPAK sebesar 69,55, Variabel PMA sebesar 0,1, Variabel Realisasi belanja modal sebesar 0,51 dan variabel realisasi belanja pegawai sebesar 0,47 . Wilayah kedua pada model pesimis yaitu wilayah Gorontalo dengann prediksi nilai PDRB sebesar 23,81 dengan nilai pada variabel TPAK sebesar 67,50, Variabel PMA sebesar 0,09, Variabel Realisasi belanja modal sebesar 0,46 dan variabel realisasi belanja pegawai sebesar 0,41 kemudian pada wilayah Maluku utara prediksi nilai PDRB yaitu sebesar 22,36 dengan nilai pada variabel TPAK sebesar 66,55, Variabel PMA sebesar 0,08, Variabel Realisasi belanja modal sebesar 0,42 dan variabel realisasi belanja pegawai sebesar 0,385 .

\section{KESIMPULAN DAN SARAN}

\section{A. Kesimpulan}

Berdasarkan hasil analisis dapat diambil kesimpulan

1. Hasil statistika deskriptif pada pemodelan PDRB diperoleh nilai terendah adalah 20,4 Triliun terdapat pada provinsi Maluku Utara sedangkan nilai PDRB tertinggi sebesar 1454,3 Trilliun pada DKI Jakarta. Rata-rata nilai PDRB di Indonesia pada tahun 2015 adalah sebesar 265,7 trilliun dengan standar deviasi yaitu sebesar 376,3. Faktor yang mempengaruhi pertumbuhan ekonomi yaitu TPAK $\left(\mathrm{X}_{1}\right)$, PMA $\left(\mathrm{X}_{2}\right)$, Realisasai Belanja Modal $\left(\mathrm{X}_{3}\right)$ dan Realisasi Gaji Pegawai $\left(\mathrm{X}_{4}\right)$. Titik knot terbaik yang didapatkan pada analisis Regresi Nonparametrik Spline yaitu kombinasi knot 2-3-2-3 dan nilai GCV minimum 3150,55 dengan nilai $R s q$ sebesar 99,207 \%. Model terbaik yang didapatkan adalah sebagai berikut.

$$
\begin{aligned}
\hat{y}= & -576,916+7,506 x_{1}-15,783\left(x_{1}-64,656\right)_{+}^{1}-61,509\left(x_{1}-76,429\right)_{+}^{1}+13,617 x_{2}- \\
& 7867,562\left(x_{2}-1,290\right)_{+}^{1}+14945,791\left(x_{2}-1,875\right)_{+}^{1}-23655,847\left(x_{2}-4,802\right)_{+}^{1}+64,546 x_{3}+ \\
& 3,396\left(x_{3}-5,242\right)_{+}^{1}-462,376\left(x_{3}-18,692\right)_{+}^{1}+263,511 x_{4}-3013,684\left(x_{4}-4,923\right)_{+}^{1}+ \\
& 2447,259\left(x_{4}-7,502\right)_{+}^{1}+593,274\left(x_{4}-17,692\right)_{+}^{1}
\end{aligned}
$$

2. Model Prediksi optimis yang paling maksimum diperoleh nilai PDRB sebesar 1462,57 Triliun di wilayah DKI Jakarta dengan variabel-variabel prediktor sebesar 79,58 untuk variabel TPAK, Variabel PMA sebesar 3,9, Realisasi belanja modal sebesar 22,69 dan Realisasi belanja pegawai sebesar 22,15.

\section{B. Saran}

Saran dalam penelitian ini mengenai pemodelan PDRB sebagai indikator pertumbuhan ekonomi di Indonesia tahun 2015 yaitu sebagai berikut.

1. Dalam penelitian ini perlu adanya faktor penunjang dari faktor ekonomi maupun non-ekonomi setiap wilayahnya.

2. Penelitian selanjutnya dapat menambahkan variabel yang mempengaruhi berdasarkan rujukan sebelumnya misalnya variabel Jumlah industri besar dan sedang.

3. Pemerintah dapat menjadikan model prediksi sebagai bahan pertimbangan mengenai kesenjangan ekonomi yang terjadi antar provinsi di Indonesia.

\section{DAFTAR PUSTAKA}

[1] O. Sinaga,16 $02 \quad$ 2015.[Online]. Available:https://m.tempo .co/read/news/2015/02/16/090642957/pertumbuhan-ekonomi-indonesiamelambat-apa-sebabnya.

[2] BPS, "Laporan Perekonomian Indonesia," BPS, Surabaya, 2016.

[3] BI, 2013. [Online]. Available: www.bi.go.id.

[4] OJK, "Memacu Pertumbuhan Ekonomi Melalui Sektor Jasa Keuangan Yang Kontributif, Stabil dan Inklusif," OJK, 2015.

[5] A. Fauzan, "Analisis Pengaruh Investasi, Tenaga Kerja, dan Tingkat Pendidikan Terhadap Pertumbuhan Ekonomi," Skripsi, 2014. 
[6] E. K. Litawati, "Pendekatan Regresi Nonparametrik Spline Untuk Pemodelan Laju Pertumbuhan Ekonomi (LPE) di Jawa Timur," JURNAL SAINS DAN SENI POMITS Vol. 2, No.2, 2013.

[7] A. Nurindah, "Pemodelan Produk Domestik Regional Bruto (PDRB) Provinsi Jawa Tengah," Tugas Akhir Sarjana, 2015.

[8] Y. Kornelis, "Sistem Informasi Pelaporan Statistik Penjualan pada PT.Wira Eka Persadatama," p. 8, 2013.

[9] R. Eubank, Spline Smoothing and Nonparametric Regression, New York: Marcel Deker, 1999.

[10] N. R. Draper and H. Smith, Applied Regression Analysis, New York: Wiley, 1998.

[17] W. Soeparno, "Analisis Indikator Makro Ekonomi Terhadap Pertumbuhan Ekonomi Kabupaten/Kota Di Sumatera Utara," Tesis, 2011.
[11] D. Gujarati, Basic Econometrics, Tata McGraw-Hill Education, 2009.

[12] W. Daniel, Statistika Nonparametrik, PT.Gramedia, 1989.

[13] Alam, "Ekonomi untuk SMA dan MA XI," Jakarta, Erlangga, 2007, p. 25 .

[14] Departemen Statistik Ekonomi dan Moneter Bank Indonesia, "Produk Domestik Regional Bruto (PDRB)," Bank Indonesia, Jakarta, 2013.

[15] BI, "Laporan Perekonomian Indonesia 2014," BI, Jakarta, 2016.

[16] Bappenas, "Laporan Hasil Kajian Pengembangan Ekonometrika," 2004. [Online]. Available: https:// www.bappenas.go.id. 